\title{
Novel Modules to Teach Evolutionary Medicine: an Australian and a Swiss Experience
}

\author{
Frank Rühli $^{1}$ • Martin Haeusler ${ }^{1,2}$ • Arthur Saniotis ${ }^{3}$ - Maciej Henneberg ${ }^{1,3}$
}

Published online: 18 April 2016

(C) The Author(s) 2016. This article is published with open access at Springerlink.com

\begin{abstract}
Objectives Evolutionary medicine is a growing field focusing on the evolutionary basis of human diseases and their changes through time. The introduction of concepts of long- and shortterm evolution into the medical curricula is essential to acknowledge the variability of human biology.

Methods Three courses of the EM taught at the University of Zurich and the University of Adelaide are presented by giving their general descriptions, full curricula, and the results of anonymized student evaluations.

Results The presented courses meet a growing need and were positively received by the students. Most importantly, they seem to stimulate critical thinking about issues relating to health and evolution.

Conclusions The incorporation of these topics into curricula will allow future practitioners of health-related professions to apply principles of human evolution and its forces in their work.
\end{abstract}

Keywords Disease - Curricula · Evolutionary medicine · Medical school

\section{Introduction and Rationale}

Humans are not only the product of a long evolutionary process but are also continuously evolving $[1,2]$. We therefore

Frank Rühli

frank.ruehli@iem.uzh.ch

1 Institute of Evolutionary Medicine, University of Zurich, Zurich, Switzerland

2 Institute of Anatomy, University of Zurich, Zurich, Switzerland

3 Biological Anthropology and Comparative Anatomy Unit, Medical School, The University of Adelaide, Adelaide, Australia show variation of anatomical structures and physiological processes, as well as disease patterns and prevalences (Fig. 1). Intergenerational changes of human anatomy and pathology have been frequently reported and are of foremost interest (e.g., for surgeons). Significant changes in morphological characteristics include the following: decrease in the robusticity of the musculoskeletal apparatus (gracilization) [3-5], weight and height [6], microcranialization and brachycephalization (reduction in braincase size and change of its shape) [7-9], reductions in the size and number of teeth [10], spinal morphology alterations [11, 12], changing frequencies of tarsal coalitions [13], increase of the frequency of some arteries (median) [14], and decrease of others (thyroidea ima) [15]. These alterations are all likely to be at least partially the result of structural reductions in response to technology diminishing the need for the use of physical strength. Aside from genetic changes, they therefore may also occur from epigenetic alterations due to differing environmental pressures such as a reduction of chewing effort in the processing of food, leading to reduction in jaw size $[16,17]$. Moreover, the ubiquitous low-back problems of modern humans, shoulder impingement, hip and knee osteoarthritis, and other musculoskeletal diseases are often attributed to anatomical variants inherited from our early hominin ancestors as trade-offs to the evolution of bipedal locomotion [18-25]. However, the degree of variability of human morphology is often neglected in traditional medical curricula. These facts require the introduction of concepts of long- and short-term evolution into medical curricula.

\section{Evolutionary Medicine Curricula}

The call for the incorporation of evolutionary topics into the modern biomedical curriculum has been raised for 


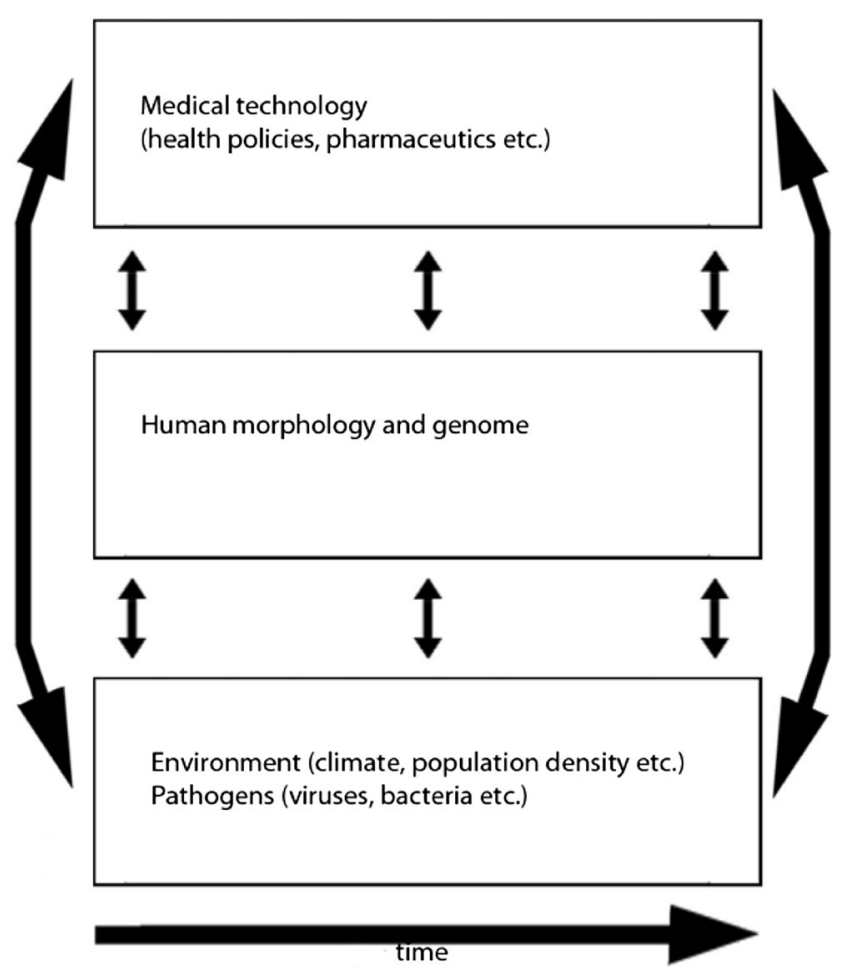

Fig. 1 Interactions of humans, environment, and medical technology as addressed by evolutionary medicine

more than 10 years [26]. However, no specific large, medically oriented evolutionary medicine (EM) research unit existed until 2010 [27-29]. Since then, the number of top universities offering EM-related teaching is steadily increasing $[27,29]$. Thus, the full biomedical academic potential of EM is still largely untapped, especially when it comes to evidence-based applications. In terms of practicality, the inclusion of a so-called clinical anatomy skills lab into an EM research center-where clinicians train and experiment, e.g., on human morphological variability in close collaboration with anatomists in the dissection room-may provide an appropriate launching place for EM studies on such human morphological microevolution.

A plethora of EM-related topics to be taught in medical schools could be named (Table 1). These combine, e.g., themes of clinical medicine, basic research such as genetics, human biology, physical and social anthropology, and archeology. The benefit of such evolutionary-based academic education has been laid out recently by a consensus paper, which highlighted the rationale for such teaching, the learning objectives for both-premedical and medical competencies - as well as the general integrative power of EM teaching [30]. Furthermore, it is apparently feasible to acquire third party funding for this particular field of research [29], thus combining graduate and postgraduate teaching and research of EM within state-of-the-art academic facilities (such as the abovementioned clinical anatomy skills lab). On a larger
Table 1 Selection of lecture and seminar topics from our courses of evolutionary medicine

Titles of lectures and seminars

- Adaptive explanations of reaction to infectious diseases.

- Host and parasite co-evolution, evolutionary history of major chronic infections: treponematoses, leprosy, tuberculosis

- Demographic future of humankind, demographic modeling

- The role of disease in society, perceptions of health in diverse cultures

- Future medical developments: nanotechnology, genetic engineering, recombinant DNA

- Cultural roles of children, adolescents, adults and elderly - how they impact on health. Human senescence, the aging society of the future

- Psychological health in various stages of life. Impact of disease on human individual relations

- Perception of psychiatric ailments in various cultures

- Modern maladaptations-drugs and other addictive agents; socioeconomic mental health inequalities

- Human dietary adaptations ("natural" human diet), mismatch with modern nutrition

- Cross-cultural nutritional practices, food taboos, malnutrition, obesity

- The role of sexual relationships in nondirectional forces of evolution: inbreeding and incest avoidance. Assortative mating and its consequences. Cultural differences

- Feminine approaches to the body and health

- Masculine body image, men's health

- Sexual disease, social structure and public health

- Adaptive responses of human body, short-term adaptive trends (microevolution, secular trends)

- The future of humankind (discussion)

- Ethics in future medical practice and public health

scale, this could result in worldwide collaborations and implementation in leading health science schools around the globe.

\section{The Modules: Aims and Outline}

Here, we present three novel courses held between autumn 2012 and spring 2015 that embed the teaching of secular trends in the human body and pathology: (1) a full semester undergraduate course on evolution and health introduced in 2012 at the University of Adelaide as an elective for medical students, and a senior (level III) course for health sciences students; (2) an intensive master-level postgraduate "block course" for science students introduced at the University of Zurich in 2013, the first tertiary level full course in evolutionary medicine to be taught in Switzerland; and (3) an elective course for medical undergraduate students introduced in 2014 at the University of Zurich.

Based on our own original data of temporal changes in human body structures - e.g., the prevalence of additional arteries or of spina bifida occulta, and palaeopathological 
observations - such topics are addressed both in a classical lecture format and in interactive practicals and seminars corun by students.

The first module at the University of Adelaide has a maximum of 50 students quota and consists of $4 \mathrm{~h}$ of contact per week for 12 weeks. However, students are expected to spend about at least another $4 \mathrm{~h}$ per week on researching for their written tasks that comprise the assessment. In the past, some students have reported spending more than this amount of time on research and reading and writing. Thus, $4 \mathrm{~h}$ would be the minimum time required. The course is offered every year and comprises lectures, seminars, discussion, and selfdirected learning activities. Selected course learning objectives are listed in Table 2.

The second module, the block course at the University of Zurich, is available to graduates of the 3-year degree (license = $\mathrm{BSc}$ ) who are registered for a Master of Biology degree. It is limited to 20 students only to provide an opportunity for small group work and development of individual interests. It is run over 4 weeks ( 3.5 days per week) and consists of $34 \mathrm{~h}$ of lectures and $39 \mathrm{~h}$ of seminars as well as practicals in osteology, bone pathology, imaging techniques, ancient DNA analysis, and analysis of large health-related datasets. The main objectives of the block course are listed in Table 3.

The third module is available to medical undergraduate and first year medical Master students of the University of Zurich (i.e., second to fourth year medical students). During these three years, the students have to choose 6 different modules among about 35 modules offered in total. The module in

Table 2 Course learning objectives Adelaide

\begin{tabular}{|c|c|}
\hline 1. & Understanding of forces of evolution \\
\hline 2. & How technology influences human evolution \\
\hline 3. & Future consequences of modern medical practices \\
\hline 4. & $\begin{array}{l}\text { Microevolutionary changes of human anatomy and } \\
\text { physiology in the last few thousand years }\end{array}$ \\
\hline 5. & $\begin{array}{l}\text { Impact of migration, marriage customs, and morality } \\
\text { on forces of evolution (inbreeding, genetic load, } \\
\text { gene flow) }\end{array}$ \\
\hline 6. & $\begin{array}{l}\text { Relationship between current medical practice } \\
\text { and forces of evolution (mortality, fertility, } \\
\text { mutations) }\end{array}$ \\
\hline 7. & $\begin{array}{l}\text { Ethical issues of evolutionary medicine } \\
\text { (avoidance of eugenic errors) }\end{array}$ \\
\hline 8. & $\begin{array}{l}\text { Socioeconomic conditions and physical development } \\
\text { of children }\end{array}$ \\
\hline 9. & Appreciation of cultural differences in health outcomes \\
\hline 10. & $\begin{array}{l}\text { Ability to analyze health of communities in evolutionary } \\
\text { perspective }\end{array}$ \\
\hline 11. & $\begin{array}{l}\text { Ability to prepare a seminar presentation on a specific } \\
\text { topic }\end{array}$ \\
\hline 12. & $\begin{array}{l}\text { Ability to engage in a meaningful, structured } \\
\text { discussion of a specific topic }\end{array}$ \\
\hline
\end{tabular}

Table 3 Selected course learning objectives Zurich

\begin{tabular}{|c|c|}
\hline & e forces of evolution and their impact on human \\
\hline & $\begin{array}{l}\text { To formulate how evolution of pathogens, technology and } \\
\text { environment influences human health }\end{array}$ \\
\hline & $\begin{array}{l}\text { To discuss microevolutionary changes of human anatomy } \\
\text { and physiology in the last few centuries }\end{array}$ \\
\hline & $\begin{array}{l}\text { To examine the macroevolutionary origin of musculoskeletal } \\
\text { disorders as possible trade-offs to the evolution of bipedal } \\
\text { locomotion }\end{array}$ \\
\hline & $\begin{array}{l}\text { To summarize state-of-the-art research on ancient DNA } \\
\text { (for example, next-generation sequencing) }\end{array}$ \\
\hline & $\begin{array}{l}\text { To address ethical issues of evolutionary medicine (use } \\
\text { of ancient remains, etc.) }\end{array}$ \\
\hline & $\begin{array}{l}\text { To appreciate the impact of the concept of evolutionary } \\
\text { medicine on biomedical science and general society }\end{array}$ \\
\hline
\end{tabular}

evolutionary medicine consists of 7 half days ( $4 \mathrm{~h}$ each) and is offered every semester, with a maximum of 15 students. The structure of the course and the learning objectives are similar to those of the block course, although the seminars and practicals are less extensive.

Common to all three courses is that they require studentdirected learning. That is, students must take responsibility in shaping the focus of their work and in formulating arguments within that work. Lectures and seminars, both with interactive discussion, are principal learning and teaching modes. Since the courses attempt to integrate knowledge of a number of disciplines, active student participation in lectures and seminars is required. Lectures integrate knowledge already possessed by students with new approaches to its interpretation as well as to supplement knowledge where it is found to be missing. Seminars are fully interactive discussions focusing on specific topics, but allowing branching out into topics identified as important during discussions.

Each student has to prepare an oral presentation to start a seminar discussion. In addition, in the Adelaide course, each student has to write an essay on the topic chosen jointly by a student and a course coordinator so that student interests are provided for while the topic fits into the broader scope of course knowledge. The Adelaide course has a strong focus on formative feedback.

All three courses are interdisciplinary and comprise materials delivered by lecturers from different disciplines, and also, the classes include students from different background. The courses encourage students to think, debate, and challenge taken-for-granted ideas about health care.

\section{Assessment of the Courses}

Assessment of the Adelaide course is based on the following five principles: (1) assessment must encourage and reinforce 
learning; (2) assessment must measure achievement of the stated learning objectives; (3) assessment must enable robust and fair judgments about student performance; (4) assessment practices must be fair and equitable to students and give them the opportunity to demonstrate what they have learned; and (5) assessment must maintain academic standards. An assessment summary is provided in Table 4.

The block course at the University of Zurich (i.e., second module) is assessed exclusively by a final exam as this is viewed as the most objective assessment method that is best verifiable and resistant against appeals. The third module aimed at medical undergraduate students of the University of Zurich is not given marks. To pass, the students have to give an oral presentation, attend the full course, and participate actively.

At the end of the courses, the students were asked to anonymously review the course. Survey questions are listed in Tables 5 and 6 for the courses at the University of Adelaide and Zurich, respectively.

\section{Results}

Participation in the anonymous survey at the University of Adelaide was 11 of 17 enrolled students in the 2012 course, 13 of 19 in 2013, and 13 of 20 in 2014. Over the last 2 years, $82 \%$ of the University of Adelaide students assessed the overall quality of the course on a seven-score scale as very good to excellent (Table 5). Specifically, they assessed that the course uses appropriate strategies to engage them in their learning (mean 6.3 out of 7 points), and it helps them to develop their thinking skills (mean 6.3 out of 7 points). Students' comments on what are the best aspects of the undergraduate Adelaide course are as follows:

- Learning new ideas and things from a new perspective.

- Content in itself was extremely rewarding.

- Broad range of topics, which is very interesting.

- Covers all issues of evolution and stimulates students' critical thinking.

- It is a new course and covers areas of science that have been mentioned in other subjects but in a different way of thinking about them.
Table 5 Survey questions at the University of Adelaide course

Q1. This course has clearly identified learning outcomes. (5)

Q2. This course is well organized. (6)

Q3. This course has a workload that is appropriate for the achievement of its learning outcomes. (6)

Q4. Appropriate strategies to engage me in my learning. (7)

Q5. This course uses appropriate online resources and technologies to help me achieve its learning outcomes. (6)

Q6. This course uses methods of assessment that help me achieve its learning outcomes. (6)

Q7. This course helps me to develop my thinking skills (e.g., problem solving, critical analysis). (6)

Q8. This course has a learning environment that takes into account student diversity. (7)

Q9. My learning in this course is supported by effective feedback. (6)

Q10. Overall, I am satisfied with the quality of this course. (7)

Free-answer questions:

Q11. What are the best aspects of this course, and why?

Q12. This course could be changed in the following ways to improve my learning

Each question has seven possible answers from $1=$ strongly disagree to $7=$ strongly agree. Median responses in brackets

- It encourages thinking widely about issues relating to health and evolution.

The overall return rate of the anonymous survey of the block course for biology students at the University of Zurich was $98 \%$. The students assessed the overall quality of the course on a five-score scale as follows: $57 \%$ of students in 2013 and $26 \%$ in 2014 stated that they are very satisfied, whereas the remainder (43 and $68 \%$, respectively) stated that they were satisfied (with only one student in 2014 (5\%) being neutral and none unsatisfied). In the module for University of Zurich medical students, the participation rate in the survey was $90 \%$. The high degree of overall satisfaction with the course was similar to that of the biology students at the University of Zurich (29 and $62 \%$ were very satisfied in 2014 and 2015, respectively, and 64 and $38 \%$, respectively, were satisfied, with one of the 2014 students (7\%) being
Table 4 Assessment summary of the Adelaide course

\begin{tabular}{llll}
\hline Assessment task & Type of assessment task & Weighting (\%) & $\begin{array}{l}\text { Learning course } \\
\text { objectives being } \\
\text { addressed (cf. Table 2) }\end{array}$ \\
\hline $\begin{array}{l}\text { Oral presentation } \\
\text { Mid-term test }\end{array}$ & Formative and summative & $10 \%$ & $1,5,10$ \\
Essay & Summative & $20 \%$ & $1,2,3,4,8$ \\
Active participation in seminars & Formative and summative & $30 \%$ & All (1-12) \\
Final examination & Formative and summative & $10 \%$ & All (1-12) \\
& Summative & $30 \%$ & $1-10$ \\
\hline
\end{tabular}


Table 6 Survey questions at the University of Zurich courses

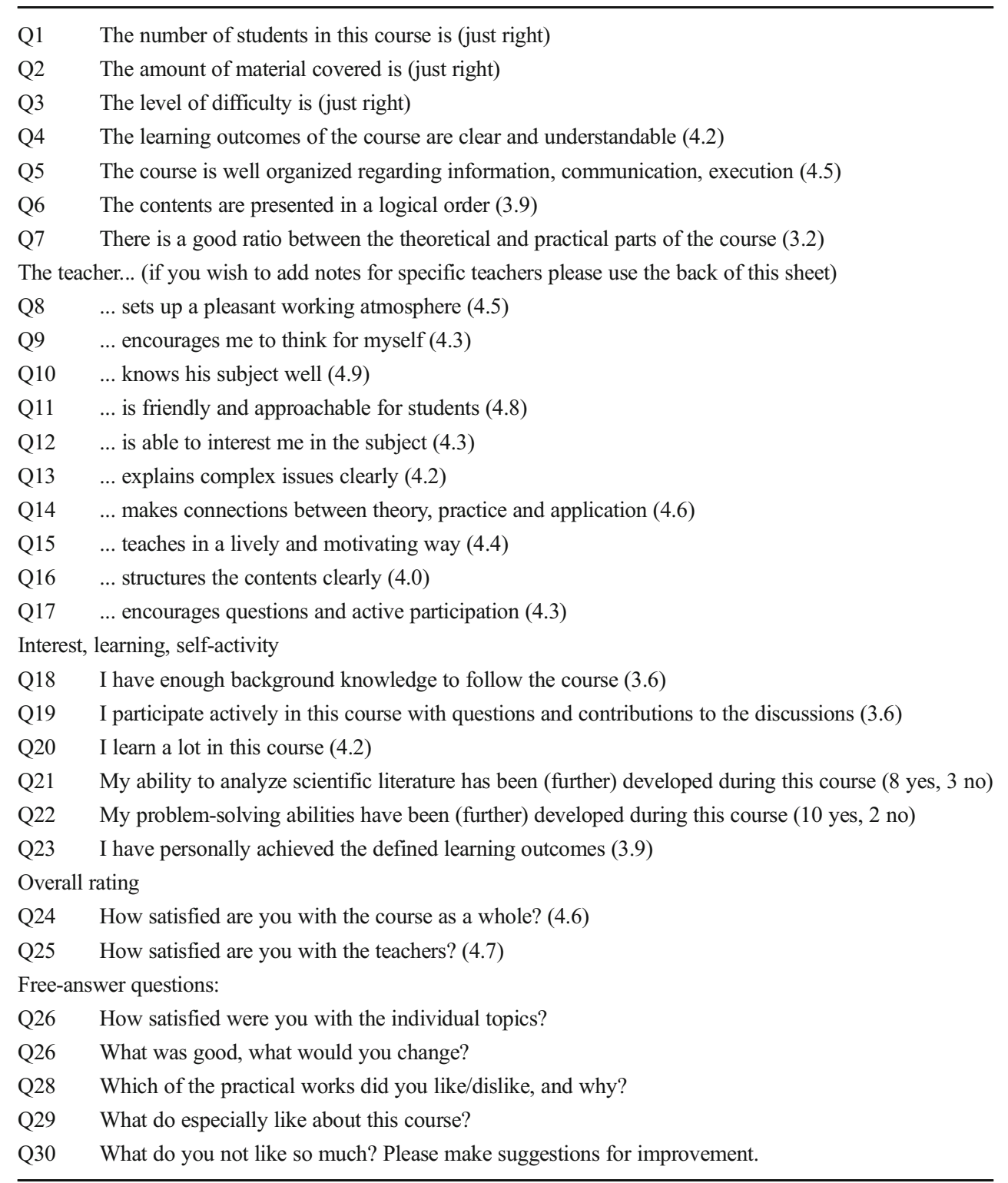

Each question has five possible answers from $1=$ strongly disagree to $5=$ strongly agree. Median responses in brackets for spring semester 2015 (module 3) neutral). Comments on what are the best aspects of the postgraduate Zurich course are as follows:

- The insights of the development and the epidemics of disease are very helpful for biologists.

- Covers a wide range of research fields such as medicine, genetics, anthropology, and even history and ethics, which makes it very diverse and interesting.

- Small group work with specialists. Lots of teachers giving new perspectives.

- Good practicals giving access to actual specimens of bone pathologies and ancient DNA analysis.

- The course stimulates critical thinking.

\section{Discussion and Outlook}

The presented courses obviously meet a growing need, and they were positively received by the students. The format of the courses seems to be appropriate yet minor organizational and content changes based on actual evaluation may also happen in the future. Most importantly, the actual courses seem to stimulate critical thinking about issues relating to health and evolution. Another significant outcome measure is the direct involvement of students into full research activities, which already resulted in various publications [31-36]. Last but not least, the courses lead to a growing number of Bachelor, Master, and $\mathrm{PhD}$ students at the involved institutes. 
More universally, the benefit of evolutionary-based academic education has been laid out only recently by a consensus paper, which highlighted the rationale for such teaching, the learning objectives for both-premedical and medical competencies - as well as the general integrative power of EM teaching [30]. The incorporation of principles of human evolution and its forces for future medical practitioners is thus needed, since an understanding of the evolutionary dynamics of the human body will be able to optimize medical therapies and public health policies. Presently, the number of universities offering EM related teaching is steadily increasing [27, 29]. The courses offered in EM at the Universities of Zurich and Adelaide are well received by students. A plethora of intergenerational change-related topics to be taught in medical schools could be named by the students (see above). They could combine elements of clinical medicine, public health, medical basic science research, human biology, physical and social anthropology, economic history, and even archeology.

A fundamental issue arising from this understanding is the biocultural interactions that expedite human vulnerability to disease. For example, modern humans are being increasingly outmaneuvered by resistant bacterial strains and arthropod vectors. This needs to be quickly addressed since modern living (cultural behaviors) facilitates the spread and transmission of resistant pathogens due to novel environments such as global travels. Another biocultural interactions leading to morphological dysfunction are human made environmental contaminants, which may potentially reduce male reproductive health with consequential declining fertility [37-40]. A third major problem of biocultural interaction and morphological transition based on individual genetic endowments is the current pandemic of overweight and obesity in many countries. Several thinkers in EM have referred to this pandemic as a classical "mismatch" or "discordance" between biological evolution and cultural change [41-43].

A general practitioner may not directly heal a patient using only evolutionary medicine principles, but without a little knowledge of the evolutionary dynamics of the human body he/she certainly will not be able to provide the best, individualized diagnosis, medico-social advice, and prescribe optimal personal treatment [44].

\section{Conclusion}

At this time, researchers and teachers in EM need to encourage medical and health science professionals to explore the evolutionary principles that inform human health and disease. The approach should be multifactorial, using latest research in EM, as well as wider media exposure, in order to inform the scientific community and the general public. Antolin et al. [40] endorse a "big picture" approach to teaching EM via the inclusion of reference frameworks for improving information transfer and student retention. Moreover, students may become more interested in evolutionary concepts by embedding them in sociocultural behaviors. Current public interest in future human evolution is a growing area of EM by which it can engender ideas for medical and public health interventions. The expansion of EM in research and pedagogical areas is crucial due to ongoing human microevolution, which may present unknown challenges to future humans.

\section{Detailed Curricula}

The Adelaide course was run for the third time in late 2014, the Zurich courses for medical and science students are run for the fifth and third time, respectively, by spring 2016 . To meet the high demand, they will be offered twice a year starting from 2015. Curricula are evolving in response to teachers and students suggestions. Full curricula and detailed course descriptions are available from the authors upon request.

Authors' Contribution Frank Rühli, MD, PhD, is a Professor of Anatomy and the founder and director of the Institute of Evolutionary Medicine at the University of Zurich. He has wide anatomy teaching experience both in Europe and Australia.

Martin Haeusler, $\mathrm{PhD}, \mathrm{MD}$, is head of the morphology group at the Institute of Evolutionary Medicine and senior lecturer at the Institute of Anatomy, University of Zurich. He has 12 years experience in teaching.

Arthur Saniotis, $\mathrm{PhD}$ is a Research Fellow at the School of Medical Sciences at the University of Adelaide. He has 18 years experience teaching at several universities in Australia and in Asia.

Maciej Henneberg, PhD, DSc, is a Wood Jones Professor of Anatomy at the University of Adelaide. He is also an International Fellow of the UBVO at Oxford University. For the last 41 years he has taught at universities in the USA, UK, South Africa, and Poland.

\section{Compliance with Ethical Standards}

Grant Support This study was supported by the Mäxi Foundation, Zurich.

Open Access This article is distributed under the terms of the Creative Commons Attribution 4.0 International License (http:// creativecommons.org/licenses/by/4.0/), which permits unrestricted use, distribution, and reproduction in any medium, provided you give appropriate credit to the original author(s) and the source, provide a link to the Creative Commons license, and indicate if changes were made. 


\section{References}

1. Balter M. Are humans still evolving? Science. 2005;309(5732): 234-7. doi:10.1126/science.309.5732.234.

2. Hawks J. Still evolving (after all these years). Sci Am. 2014;311(3): 86-91.

3. Ruff CB, Holt B, Niskanen M, Sladek V, Berner M, Garofalo E, et al. Gradual decline in mobility with the adoption of food production in Europe. Proceed Natl Acad Sci. 2015;112:7147-52. doi:10. 1073/pnas.1502932112.

4. Schwidetzky I. Das Grazilisierungsproblem. Ein Brückenschlag zwischen Rassengeschichte und Konstitutionsforschung. Homo. 13:188-95.

5. Ruff CB. Variation in human body size and shape. Ann Rev Anthropol. 2002;31:211-32.

6. Katzmarzyk PT, Leonard WR. Climatic influences on human body size and proportions: Ecological adaptations and secular trends. Am J Phys Anthropol. 1998;106(4):483-503.

7. Henneberg M. The influence of natural selection on brachycephalization in Poland. Stud Phys Anthropol. 1976;2:3-19.

8. Henneberg M, Budnik A, Pezacka M, Puch A. The mechanism of brachycephalization: differential susceptibility to infectious diseases during childhood. A preliminary report. Przeglad Antropol. 1984;50:332-3.

9. Henneberg M. Decrease of human skull size in the Holocene. Hum Biol. 1988;60:395-405.

10. Brace CL, Rosenberg KR, Hunt KD. Gradual change in human tooth size in the late Pleistocene and post-Pleistocene. Evolution. 1987;41(4):705-20. doi:10.2307/2408882.

11. Rühli FJ, Henneberg M. Clinical perspectives on secular trends of intervertebral foramen diameters in an industrialized European society. Eur Spine J. 2004;13(8):733-9. doi:10.1007/S00586-004-0682-8.

12. Rühli FJ. Osteometric variation of the human spine in Central Europe by historic time period and its microevolutionary implications. PhD Thesis, University of Adelaide; 2003.

13. Solomon LB, Rühli FJ, Taylor J, Ferris L, Pope R, Henneberg M. A dissection and computer tomograph study of tarsal coalitions in 100 cadaver feet. J Orthop Res. 2003;21(2):352-8. doi:10.1016/S07360266(02)00131-6.

14. Henneberg M, George BJ. Possible secular trend in the incidence of an anatomical variant: median artery of the forearm. Am J Phys Anthropol. 1995;96(4):329-34.

15. Bhatia K, Ghabriel M, Henneberg M. Anatomical variations in the branches of the human arch of the aorta: a possible increase in recent times. Folia Morphol (Warsz). 2005;64:217-23.

16. Corruccini RS. Australian aboriginal tooth succession, interproximal attrition, and Begg's theory. Am J Orthod Dentofacial Orthop. 1990;97(4):349-57. doi:10.1016/0889-5406(90)70107-N.

17. Rose JC, Roblee RD. Origins of dental crowding and malocclusions: an anthropological perspective. Compend Contin Educ Dent. 2009;30(5):292-300.

18. Putz RLV, Müller-Gerbl M. The vertebral column - a phylogenetic failure? A theory explaining the function and vulnerability of the human spine. Clin Anat. 1996;9:205-12.

19. Lewis J, Green A, Yizhat Z, Pennington D. Subacromial impingement syndrome: has evolution failed us? Physiotherapy. 2001;87:191-8.

20. Hogervorst T, Bouma H, de Boer SF, de Vos J. Human hip impingement morphology: an evolutionary explanation. J Bone Joint Surg Br. 2011;93(6):769-76. doi:10.1302/0301-620X.93B6.25149.

21. Haeusler M, Schiess R, Boeni T. New vertebral and rib material point to modern bauplan of the Nariokotome Homo erectus skeleton. J Hum Evol. 2011;61:575-82.

22. Haeusler M, Schiess R, Boeni T. Evidence for juvenile disc herniation in a Homo erectus boy skeleton. Spine. 2013;38:123-8. doi: 10.1097/BRS.0b013e31827cd245.
23. Schiess R, Haeusler M. No skeletal dysplasia in the Nariokotome boy KNM-WT 15000 (Homo erectus): a reassessment of congenital pathologies of the vertebral column. Am J Phys Anthropol. 2013;150:365-74. doi:10.1002/ajpa.22211.

24. Schiess R, Boeni T, Rühli F, Haeusler M. Revisiting scoliosis in the KNM-WT 15000 Homo erectus skeleton. J Hum Evol. 2014;67: 48-59. doi:10.1016/j.jhevol.2013.12.009.

25. Craik JD, Mallina R, Ramasamy V, Little NJ. Human evolution and tears of the rotator cuff. Int Orthop. 2014;38:547-52. doi:10.1007/ s00264-013-2204-y.

26. Charlton BG. A syllabus for evolutionary medicine. J R Soc Med. 1997;90(7):397-9.

27. Pennisi E. Darwin applies to medical school. Science. 2009;324(5924):162-3. doi:10.1126/science.324.5924.162a.

28. Minogue K. Mummies for medicine. Science. 2010;330(6007): 1027. doi:10.1126/science.330.6007.1027-a.

29. Dolgin E. Universities evolve, looking to Darwin for new medical insights. Nat Med. 2010;16(12):1346. doi:10.1038/nm1210-1346a.

30. Nesse RM, Bergstrom CT, Ellison PT, Flier JS, Gluckman P, Govindaraju DR, et al. Making evolutionary biology a basic science for medicine. Proc Natl Acad Sci U S A. 2010;107(Suppl 1): 1800-7. doi:10.1073/pnas.0906224106.

31. Henneberg M, Grantham JP. Metabolic obesity: the role of alanine transaminase. In: Bose K, editor. Health Consequences of human central obesity. New York, USA: NOVA Science Publications; in print.

32. Henneberg M, Grantham JP. Obesity - a natural consequence of human evolution. Anthropol Rev. 2014;77:1-10.

33. Grantham JP, Staub K, Rühli FJ, Henneberg M. Modern diet and metabolic variance - a recipe for disaster? BMC Nutrition Journal. 2014;13:15.

34. Grantham JP, Henneberg M. The estrogen hypothesis of obesity. PLoS ONE. 2014;9:e99776. doi:10.1371/journal.pone.0099776.

35. Saniotis A, Henneberg M, Kumaratilake J, Grantham JP. Messing with the mind: evolutionary challenges to human brain augmentation. Front Syst Neurosci. 2014;8:152. doi:10.3389/fnsys.2014.00152.

36. Grantham J, Henneberg M. Adiposity is associated with improved neuromuscular reaction time. Med Hypotheses. 2014;83:593-8.

37. Woodruff TJ, Carlson A, Schwartz JM, Giudice LC. Proceedings of the summit on environmental challenges to reproductive health and fertility: executive summary. Fertil Steril. 2008;89(2, Supplement): e1-e20. doi:10.1016/j.fertnstert.2008.01.065.

38. Mathur P, Saradha B, Vaithinathan S. Impact of environmental toxicants on testicular function. Immunology, Endocrine \& Metabolic Agents in Medicinal Chemistry (Formerly Current Medicinal Chemistry-Immunology, Endocrine and Metabolic Agents). 2008; 8(1):79-90.

39. Stearns SC. Evolutionary medicine: its scope, interest and potential. Proc Biol Sci. 2012;279:4305-21. doi:10.1098/rspb.2012.1326.

40. Antolin MF, Jenkins KP, Bergstrom CT, Crespi BJ, De S, Hancock A, et al. Evolution and medicine in undergraduate education: a prescription for all biology students. Evolution. 2012;66(6):19912006. doi:10.1111/j.1558-5646.2011.01552.x.

41. Cordain L, Watkins BA, Florant G, Kelher M, Rogers L, Li Y. Fatty acid analysis of wild ruminant tissues: evolutionary implications for reducing diet-related chronic disease. Eur J Clin Nutr. 2002;56(3): 181-91.

42. Trevathan WR. Evolutionary medicine. Ann Rev Anthropol. 2007;36:139-54.

43. Stearns SC, Nesse RM, Govindaraju DR, Ellison PT. Evolution in health and medicine Sackler colloquium: evolutionary perspectives on health and medicine. Proc Natl Acad Sci U S A. 2010;107(Suppl 1):1691-5.

44. Henneberg M, Saniotis A. How can evolutionary medicine inform future personalized medicine? Personalized Med. 2012;9(2):171-3. 